\title{
OBITUARY
}

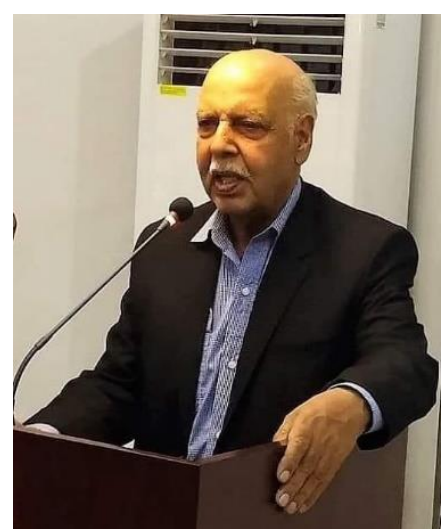

\section{Brig Professor Zafar Ahmed Malik}

\section{$(20 / 03 / 1937-29 / 11 / 2020)$}

Zafar Ahmed Malik was born on $20^{\text {th }}$ March, 1937, he spent his early years in Talagang, a small town near Rawalpindi. He completed his matriculation from Talagang High School and the interesting aspect was that all of his teachers were matric fail with the exception of one. He completed his MBBS from the University of Peshawar in 1962, and joined the army service. He qualified MCPS on $16^{\text {th }}$ February 1968, and FCPS (Anesthesiology) on $9^{\text {th }}$ February 1974. He then went to Ireland where he did his FFARCS(I) in 1976 from the Royal College of Surgeons. During his Army service he participated in the 1965 and 1971 wars with India; and was awarded with Tamgha-i-Jand and Sitara-i-Harb for his selfless and fearless services.

He became an assistant professor in Army Medical College on $14^{\text {th }}$ October 1985 and graduated to full professorship on $1^{\text {st }}$ April 2003. After retirement he joined Fauji Foundation Hospital Rawalpindi and worked there for a few years, later he joined Al Mustafa Trust for voluntary service for 14 years. It is a welfare organization.

After being diagnosed with COVID-19, he was subsequently admitted in CMH Rawalpindi, where he battled bravely for 10 days, in which a plasma exchange was also done, and he showed some signs of improvement, and was almost fit to return home; however, unfortunately developed a pulmonary embolism that lead to his tragic demise on Sunday $29^{\text {th }}$ November 2020.

I have known Brig Zafar Ahmed Malik for the past 40 years, as a colleague, friend, and brother. He was an extraordinarily intelligent individual, who achieved so much in his career, and contributed to the health and happiness of so many. We served together in CMH Rawalpindi for many years. It was known to all that he was always cheerful in the face of adversity, and in the most stressful of situations. His memory was sharp, but his words were soft. His personality would always light up the room, lifting the spirit of all around him with his jokes and stories, always narrated like a story teller, which he was. In light of his sense of humor, his friends would fondly refer to him as 'Birbul'.

I requested that his son, Dr. Asif and daughter Dr. Ambreen to write a memoire about their father. They sent me the story below, which is a beautiful reflection of who their father was.

Brig (R) Muhammad Salim, SI(M) 


\section{A STORY}

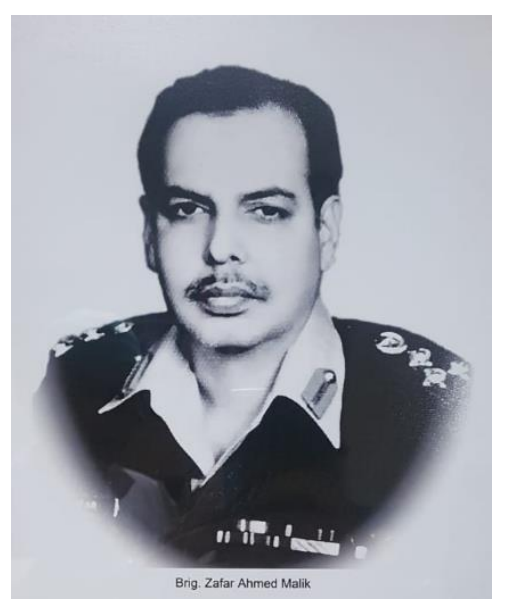

In the end we all become stories, a quote we all have come across at least once in our life, but how many times do we actually sit and think that everyone, whether good or bad, long or short becomes a story. Zafar Ahmed Malik has also become a story now. Many know him as the cute looking, tender hearted doctor who was never bothered by money, or the fact that he was usually wearing shoes from separate pairs.

Zafar was not just a doctor, he was a devoted husband, a loving father, an adoring grandfather, a caring father-in-law and a friend to many. Whether it was a restaurant or a random shop, people would recognize him, as a teacher or a friend. Never in my 20 years did I see arrogance on this man's face, his lips would always be curved in a tranquil smile and when asked the reason behind this beautiful smile he would curve his hands, smile even bigger and say something philosophical yet wise. Wisdom was one of his favorites along with the murder of pricy headphones which he would remake to his own comfort and brag about them like children brag about their grades. He also enjoyed playing golf on the condition that the ball would be tied up to a tree so he wouldn't have to walk and fetch it. He was also a foodie whether it was a hot samosa on a Sunday brunch or a steak in a restaurant, he would devour every bite and compliment the food, he even appreciated the blunder dishes his granddaughter would make. Zafar was also an award winning actor, he would always hide his anger under a big smile, he would hide his sadness by cracking random jokes and telling us tales about his past which would make the people around him hold their tummies with laughter. He never showed his disappointment and was always ready to sacrifice his happiness for the ones he loved. He was not a big fan of technology; it only made sense to him when he had to call his children when they were late. He had a theory that his fingers rejected touch screens and he couldn't use them, he would always give his expensive touch phones away and would purchase simple ones for himself. His innovative brain would always figure a way out to keep himself busy, his cabinet was full of threads, needles, and all sorts of crafty items, in order to escape from boring TV shows; he would put on his superman sunglasses which he had covered in paper and tape. He found happiness in everything, every small moment with children he would also unleash his inner baby and hop on scary rides and hold their tiny hands. As a grandfather he was full of mischiefs, he would leave extra money in his wallet so his grandkids could order fried chicken and share it with him, he would gossip with them about cute things and would tell them stories of old ghosts and chuckle when they reacted, but he never forgot to teach them significant lessons about life, which are still cherished.

He would make a friend everywhere he went regardless of age, he managed to converse about everything and would adapt to the other persons mental capacity without any hassle. He left a mark wherever he went, people still remember him and always have a wonderful memory to share.

Dada jaan you left us in your red brick home, your clothes are still resting in your closet, I still check your wallet sometimes out of habit when I am ravenous at night. Sundays are not the same anymore, I miss holding your hand and sharing my sandwich with you, I miss you in the living room, on the dining table, while watching shows, while convincing baba to take me out for dinner, you always made it easy. I know you are in a better place now, you are watching over us as we try to follow your path, I hope that we grow up to become loving persons like you.

\section{Dr. Asif (son) and Dr. Ambreen (daughter)}

